\title{
THE IMPACT OF THE ENZYME STEROID 5a-REDUCTASE 2 DEFICIENCY ON UROGENITAL BIRTH DEFECT IN MALES
}

\author{
Livia-Irina Olaru ${ }^{1}$
}

\begin{abstract}
This research work on $5 \alpha$-reductase 2 is aiming to put into evidence how a mutation of the gene codifying for this enzyme can affect the phenotype of different males, leading at a partial female phenotype. This type of research focuses on offering a scientific explanation on different health problems affecting the normal lives of some people, even from early stages of their evolution.

The experiment is focused on studying the impact of an enzyme called "steroid $5 \alpha$-reductase" on the development of male urogenital components during the embryological life. In order to study the steroid 5areductase 2 activity, the following procedures were used: isolation of a $5 \alpha$-reductase 2 gene, genomic DNA isolation, and polymerase chain reactions.

Biochemical analysis put into evidence two mutations representing opposite poles of disease manifestation, i.e. feminization of external genitalia versus predominantly male development. It suggested a correlation between clinical expression and severity of the impairment of enzyme function. As mentioned by Imperato-McGinley, Guerrero, Gautier, \& Peterson (1974), one of the mutations is called "G196S mutation.” This mutation consists of a serine substitution for a glycine at position 196. In this case, the level of 5a-reductase activity was sufficient to induce partial virilization. The second type of mutation is called "G34R mutation." This mutation consists of an arginine substitution for glycine at position 34. The G34R enzyme is essentially inactive, thus giving rise to the female phenotype.
\end{abstract}

Mutations in the type 2 gene are responsible for autosomal recessive genetic disease of $5 a$-reductase deficiency.

UDC Classification: 612.577, DOI: http://dx.doi.org/10.12955/cbup.v2.473

Keywords: conversion of testosterone, dihydrotestosterone, virilization, mammals, G196S mutation, G34R mutation, steroid $5 \alpha$-reductase

\section{Introduction}

The enzyme steroid 5a-reductase, via Nicotinamide adenine dinucleotide phosphate (NADPH), catalyses the conversion of testosterone to dihydrotestosterone, which is required for embryonic differentiation of external male genitalia and prostate (shown in Figure 1); the results were confirmed by Wigley et al. (1994). As mentioned by Jenkins, Anderson, Imperato-McGinley, Wilson, \& Russel (1992), an impairment of this reaction causes a form of male pseudo hermaphroditism, in which genetic males differentiate predominantly as phenotypic females. The subsequent study of an inborn error of male phenotypic sexual differentiation, known as steroid $5 \alpha$-reductase 2 deficiency, provides formal genetic proof of the crucial role of dihydrotestosterone in androgen action.

As stated by Russell \& Wilson (1994), "Development of the male phenotype in mammals can be divided into three temporal stages, beginning with the establishment of chromosomal sex at the time of fertilization. In the second phase, gonadal sex is determined by the expression of a key regulatory gene on the Y chromosome (the testis-determining gene or SRY). Expression of this gene transforms a bipotential gonad into a fetal testis, able to synthesize testosterone and other hormones. These hormones are required for the third phase of sexual development, the establishment of male phenotypic sex. In this last stage, virilization in mammals is mediated by two steroid hormonestestosterone and dihydrotestosterone. Both hormones bind to a typical steroid hormone receptor, the androgen receptor, and activate genes containing androgen-responsive DNA sequences.”

The androgen-dependent development of male genitalia can be further divided into the phase requiring testosterone and those requiring dihydrotestosterone. Testosterone induces the virilization of the Wolffian ducts transforming these into seminal vesicles, vasa deferentia, and epididymides. Testosterone also serves as pro-hormone for the synthesis of dihydrotestosterone in a reaction

\footnotetext{
${ }^{1}$ Livia-Irina Olaru, PhD, Sanitary Post High School “Fundeni,” Bucharest, Romania, livia_irina@yahoo.com
} 
catalyzed by membrane-bound steroid 5a-reductase enzymes. Dihydrotestosterone, in turn, induces the formation of the external genitalia, urethra, and prostate.

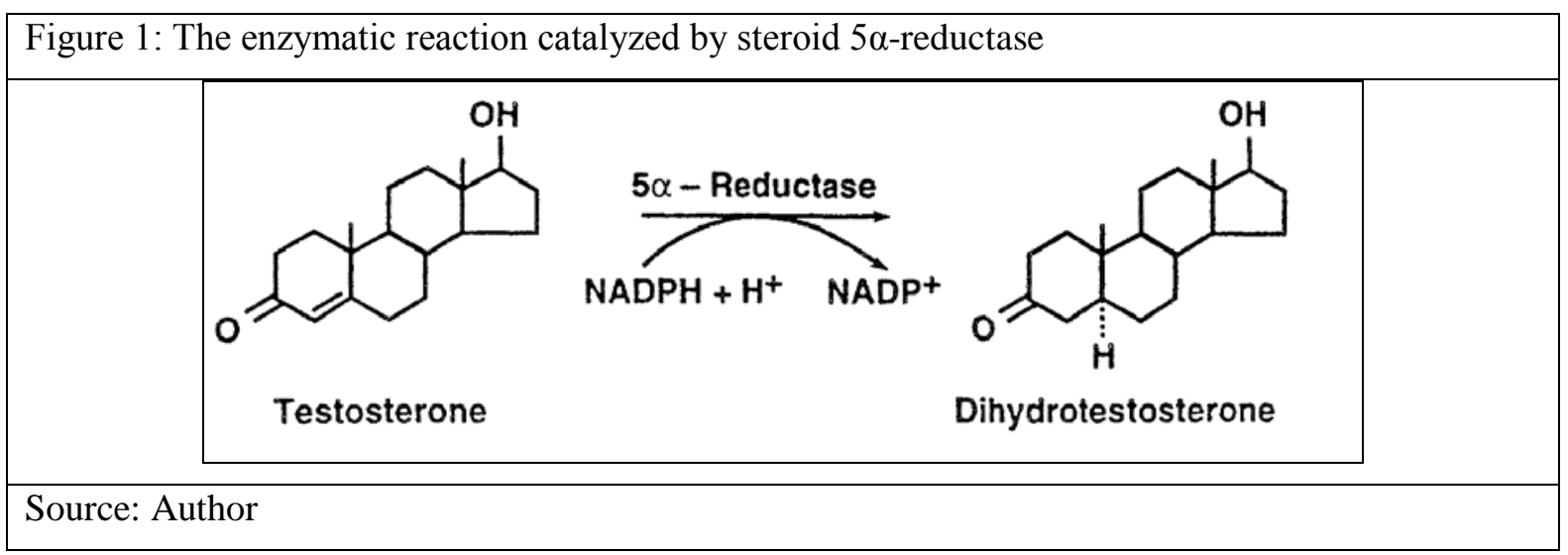

Males with genetic disease have a biochemical defect in the synthesis of dihydrotestosterone in the embryo phase, which, in turn, leads to the development of an anomaly in formation of the external genitalia and the prostate. Wilson (1991) found that this anomaly consists of a striking phenotype in which the internal genitalia (epididymis, seminal vesicles, and vas deferens) are normal, but the external genitalia resemble those of the female.

Mutations in the type 2 gene are responsible for autosomal recessive genetic disease of $5 \alpha$-reductase deficiency. The genetic basis of this mutations are not yet known, but biochemical analyses of fibroblasts and tissues from patients have revealed several different classes of mutations that affect $5 \alpha$ reductase activity.

Both human $5 \alpha$-reductase isozyme genes contain five exons separated by four introns sequences, as mentioned by Labrie, Sugimoto, Luu-The, Simard, \& Lachance (1992). The positions of the introns are essentially identical in the two genes, suggesting that the two isozymes arose by primordial gene duplication. Preliminary characterization of the mouse and rat $5 \alpha$-reductase genes indicates that this general structure is conserved in these species as well. Although the structure is shared, the two genes are located on separate chromosomes in both human and mouse. As found by Jenkins (1991) and Thipgen (1992), the gene encoding the human type 1 isozyme (gene symbol SRD5A1) is located on the distal short arm of chromosome 5 (band p15), whereas the type 2 isozyme gene (symbol SRD5A2) is located in band p23 of chromosome 2 .

\section{Methodology}

Continuing the study of Thigpen et al. (1992), we have carried out the following steps in the investigations concerning the impact of the enzyme steroid $5 \alpha$-reductase 2 deficiency on urogenital birth defect in males:

1. Isolation of a $5 \alpha$-reductase 2 gene. Bacteriophage $\lambda$ clones harboring inserts, corresponding to the $5 a$-reductase 2 gene, were isolated by high stringency hybridization screening. They used P-radiolabeled probes spanning the full length cDNA. Hybridization-positive plaques were purified through multiple rounds of screening. Bacteriophage DNA was prepared from plate lysates, and human genomic DNA. Inserts were released by digestion with the restriction enzyme Sal I before cloning into plasmid vectors (pBluescript, Stratagene Inc., La Jolla, CA). The intron-exon structure of the gene was determined by restriction enzyme mapping. Southern blotting and DNA sequence analyzing, using oligonucleotide primers, derived from the cDNA sequence. 
2. Genomic DNA isolation. Fibroblasts, biopsied from affected or normal individuals, were grown to confluence in 15-cm dishes before genomic DNA isolation. White blood cells were obtained from blood withdrawn in the presence of EDTA. Total cellular DNA was isolated with nucleic acid extractor (model 340A; Applied Biosystems, Inc., Foster City, CA) and a buffer containing $10 \mathrm{mM}$ Tris-Cl, $\mathrm{pH} 8.0$, and $1 \mathrm{mM}$ EDTA. DNA concentration was determined by fluorimetry using bisbenzimide.

3. Polymerase chain reactions. Individual exons of the $5 \alpha$-reductase 2 gene were amplified via the polymerase chain reaction (PCR), using thermostable DNA polymerases. Exon DNA, to be analyzed for the presence of single strand conformation-dependent DNA polymorphisms (SSCPs), was amplified in a $20 \mu \mathrm{l}$ reaction containing: $0.1 \mu \mathrm{l}$ genomic DNA, $1.75 \mu \mathrm{M}$ each oligonucleotide primer, $50 \mu \mathrm{M}$ each of the four deoxynucleoside triphosphates, $1.5 \%$ (vol/vol) glycerol, $50 \mathrm{mM} \mathrm{KCl}, 1.5 \mathrm{mM} \mathrm{MgCl}_{2}, 10 \mathrm{mM}$ Tris-Cl, $\mathrm{pH} 8.3$ (at $22^{\circ} \mathrm{C}$ ), $10 \mu \mathrm{Ci}\left[\mathrm{a}^{3}{ }^{32} \mathrm{P}\right] \mathrm{dCTP}$, and $3 \mathrm{U}$ of Thermostable DNA polymerase. All exons were amplified using a thermocycler program of 35 cycles of: $1 \mathrm{~min} / 94^{0} \mathrm{C}, 1 \mathrm{~min} / 68^{\circ} \mathrm{C}$, a final cycle of $1 \mathrm{~min} / 94^{0} \mathrm{C}$, and $3 \mathrm{~min} / 68^{0} \mathrm{C}$.

Exon DNA, to be sequenced. was amplified in a 50 $\mu$ reaction containing: $1.2 \mu \mathrm{g}$ genomic DNA, $20 \mu \mathrm{M}$ each oligonucleotide primer, $100 \mu \mathrm{M}$ each of the four deoxynucleoside triphosphates, $1.5 \%$ (vol/vol) glycerol, $50 \mathrm{mM} \mathrm{KCl}, 2 \mathrm{mM} \mathrm{MgCl}_{2}, 10 \mathrm{mM}$ Tris-Cl, $\mathrm{pH} 8.3$, and $3 \mathrm{U}$ of thermo stable polymerase. Thermocycler conditions were those described above. The amount of amplified DNA product in a given reaction was estimated by agarose gel electrophoresis.

\section{Results and Discussion}

The presence of mutational hotspots in the human gene is put into evidence by many researchers. The estimations indicating about 20 mutations in the $5 \alpha$-reductase 2 gene. Marumudi, Pascal, \& Bindu (2008) concluded by stating, "More than half of these affected individuals were true homozygotes, whereas $40 \%$ were either compound heterozygotes or inferred compound heterozygotes. Identical mutations have been found in individuals from widely differing geographical and ethnic backgrounds, suggesting the presence of mutational hotspots in the SRD5A2 gene.”

Biochemical analysis provided evidence for two mutations representing opposite poles of disease manifestation, i.e. feminization of external genitalia versus predominantly male development. They suggested a correlation between clinical expression and severity of the impairment of enzyme function. These results were confirmed by Imperato-McGinley et al. (1974).

Each of the substitution mutations altered an amino acid that was conserved among the sequenced $5 \alpha-$ reductase enzymes. The findings suggested that changes were in fact the cause of the disease rather than the result of random DNA polymorphisms. In accordance with this idea, it should be mentioned that no affected individual had more than two of the mutations and none of the mutations has been detected in multiple normal individuals. Identical mutations must be present in different ethnic groups, suggesting the possibility of mutational hotspots in the gene.

One so called "G196S mutation," identified in a boy with a predominant male phenotype, reduced enzyme activity, estimated at about $8 \%$ of normal level, when assayed in transfected whole cells. This mutation consists of a serine substitution by a glycine, at position 196. The mechanism by which this mutation decreased enzyme activity was presumably related to the about a 15-fold decrease in affinity of the enzyme for NADPH. The effect of this mutation on the catalytic activity of the enzyme in vivo was difficult to estimate because intracellular concentrations of NADPH varied between 50 and $400 \mu \mathrm{M}$. It was, therefore, conceivable that the level of a 5a-reductase activity in the anlage of the external genitalia in this subject was sufficient to induce partial virilization. 
In contrast, the "G34R mutation," found in subject 5R2-Los Angeles-2, reduced enzyme activity in whole cells to a greater extent. This was produced by decreasing the affinity of the enzyme for testosterone substrate by about 15 times. This mutation consists of an arginine substitution for glycine at position 34. The intracellular testosterone concentration was unknown, but was assumed to be near that of the serum in the fetus (about 50nmol/liter). At this substrate concentration, the G34R enzyme was essentially inactive, thus gave rise to the female phenotype seen in subject 5R2-Los Angeles-2.

The two substitution mutations resulted into a change of the $\mathrm{pH}$ activity profiles of the mutant enzymes. The normal $5 \alpha$-reductase enzyme showed a characteristic narrow acidic $\mathrm{pH}$ optimum, when assayed in transfected cell lysates (top panel). The G196S mutation (middle panel) showed a slightly more basic $\mathrm{pH}$ optimum (5.2 vs. 4.9 for normal). The G34R enzyme showed different $\mathrm{pH}$ profile with a broad peak of activity in the neutral to basic range (bottom panel). This $\mathrm{pH}$ activity profile was similar to that of the type 1 isozyme of $5 \alpha$-reductase.

\section{Conclusion}

Mutations of 5 - $\alpha$-reductase genes can affect both isozymes of 5 - $\alpha$-reductase (5- $\alpha$-reductase- 1 and $5-\alpha$ reductase-2). These two isozymes are codified by two different chromosomes. Thus, type 1 is codified by the chromosome 5 , while type 2 is codified by the chromosome 2 . Regulatory defects in the type 1 or type 2 genes may underline a wide variety of androgen-dependent disorders, such as male pattern baldness, acne, hirsute, and benign or malignant form of prostate cancer. In this article, we focused on the mutations of 5 - $\alpha$-reductase- 2 isozyme. The severity of mutations are completely different, as mentioned in this study.

In regard to the G196S mutation, a partial virilization can be discussed. Even if this process in only partial, people with such kind of mutation are males in accordance to their gender. On the contrary, there are people with G34R mutation—a process which involves a female phenotype. In this case, the severity of mutation is more serious, and people with this kind of mutation look completely different from their actual gender.

\section{References}

Anderson, S. D., Berman, D. M., Jenkins, E. P., \& Russell, D. W. (1991). Deletion of Steroid $5 \alpha$-reductase 2 Gene in a Male Pseudohermaphroditism. Nature, 354, 159-161. doi:10.1038/354159a0

Carpenter, T. O., Imperato-McGinley, J., Boulware, S. D., Weiss, R. M., Shackleton, C., Griffin, J. E., \& Wilson, J. D. (1990). Variable Expression of 5 $\alpha$-Reductase Deficiency Presentation with Male Phenotype in a Child of Greek Origin. Journal of Clinical Endocrinology \& Metabolism, 71(2), 318-322. doi:10.1210/jcem-71-2-318

Imperato-McGinley, J., Guerrero, L., Gautier, T., \& Peterson, R. E. (1974). Steroid 5 $\alpha$-reductase Deficiency in Man: An Inherited Form of Male Pseudohermaphroditism. Science, 186(4170), 1213-1215. doi:10.1126/science.186.4170.1213

Jenkins, E. P., Anderson, S., Imperato-McGinley, J., Wilson, J. D., \& Russel, D. W. (1992). Genetic and Pharmacological Evidence for More Than One Human Steroid 5 $\alpha$-reductase. Journal of Clinical Investment, 89(1), 293300. doi:10.1172/JCI115574

Jenkins, E. P., Hsieh, C. L., Milatovich, A., Normington, K., \& Berman, D. M. (1991). Characterization and Chromosomal Mapping of a Human Steroid 5 $\alpha$-reductase Gene and Pseudogene and Mapping of the Mouse Homologue. Genomic, 11(4), 1102-1112. doi:10.1016/0888-7543(91)90038-G

Johnson, L., George, F., Neaves, W., Rosenthal, I., Christensen, R., Decristoforo, A., Schweikert, H. U., Sauer, M., Leshin, M., Griffin, J., \& Wilson, J. (1986). Characterization of the Testicular Abnormality in a 5 $\alpha$-reductase Deficiency. Journal of Clinical Endocrinology \& Metabolism, 63(5), 1091-1099. doi:10.1210/jcem-63-5-1091

Labrie, F., Sugimoto, Y., Luu-The, V., Simard, J., \& Lachance, Y. (1992). Structure of Human Type II 5 Alpha-Reductase Gene. Endocrinology, 131(3), 1571-1573. doi:10.1210/endo.131.3.1505484

Marumudi, E., Pascal, Ph., \& Bindu, K., (2008). Molecular diagnosis of 5 $\alpha$-reductase-2 gene mutation in two Indian families with male pseudohermaphroditism. Asian Journal of Andrology, 10(5), 815-818. doi: 10.1111/j.1745-7262.2008.00350.x 
Russell, D. W., \& Wilson, J. D. (1994). Steroid 5alpha-Reductase: Two Genes/Two Enzymes. Annual Review of Biochemistry, 63, 25-61. doi: 10.1146/annurev.bi.63.070194.000325

Saiki, R. K., Gelfand, D. H., Stoffel, S., Scharf, S. J., Higuchi, R., Horn, G. T., Mullis, K. B., \& Erlich, H. A.. (1988). PrimerDirected Enzymatic Amplification of DNA with a Thermostable DNA Polymerase. Science, 239(4839), 487491. doi:10.1126/science.2448875

Shuang-Yong, X. (1986). A Rapid Method for Preparing Phage $\lambda$ DNA from Agar Plate Lysates. Gene Analysis Techniques, 3(5), 90-91. doi:10.1016/0735-0651(86)90009-9

Sinclair, A. H., Berta, P., Palmer, M., Hawkins, J. R., Griffiths, B., Smith, M., Foster, J., Frischauf, A. M., Lovell-Badge, R., \& Goodfellow, P. (1990). A Gene from the Human Sex-Determining Region Encodes a Protein with Homology to a Conserved DNA-Binding Motif. Nature, 346, 240 - 244. doi:10.1038/346240a0

Thigpen, A. E., Davis, D. L., Milatovich, A., Mendonca, B. B., Imperato-McGinley, J., Francke, U., Wilson, J. D., \& Russel, D. W. (1992). Molecular genetics of steroid 5 alpha-reductase 2 deficiency. Journal of Clinical Investment, 90(3), 799809. doi:10.1172/JCI115954

Wigley, W. C., Prihoda, J., Mowszowicz, I., Mendonca, B., New, M., Wilson, J. D., \& Russel, D. (1994). Natural Mutagenesis Study of the Human Steroid 5a-reductase 2 Isoenzyme. Biochemistry, 33(5), 12651270. doi:10.1021/bi00171a029

Wilson, J. D. (1978). Sexual Differentiation. Annual Review of Physiology, 40, 279-306. doi:10.1146/annurev.ph.40.030178. 001431

Wilson, J. D., Griffin, J. E., \& Russel, D. W. (1993). Steroid 5 $\alpha$-reductase 2 Deficiency. Endocrine Reviews, 14(5), 577-593. doi: 10.1210/edrv-14-5-577 